\title{
2-D Qsar Analysis of Benzofuran Biphenyl/ Naphthalenes as Potent PTPase-1B Inhibitors
}

\section{Darpan Kaushik and Suroor A. Khan}

\author{
Faculty of Pharmacy, Jamia Hamdard University, New Delhi-110062, India
}

Insulin resistance is associated with a defect in protein tyrosine phosphorylation in the insulin signal transduction cascade. PTPase enzyme dephosphorylates the active form of insulin receptor and thus attenuates its tyrosine kinase activity, therefore the need of potent PTPase inhibitor is there with that intention the QSAR was performed. Quantitative structure-activity relationship (QSAR) has been established on a series of compounds of novel benzofuran biphenyl/naphthalene's analogs using SYSTAT (Version 7.0) software, for their protein tyrosine phosphatase (PTPase-1B) inhibitor activity, in order to understand the essential structural requirement for binding with the receptor. Among several 2D QSAR models, one for a series was selected on the basis of high correlation coefficient, least standard deviation, $\&$ high value of significance for maximum number of subject was considered. The interpreted data signify the essentiality of hydrophobic character at $\mathrm{X}$ in the designing of the new PTPase -1B inhibitors of naphthalene analogs but not in biphenyl derivatives as shown in earlier result.

Correspondence to:

Darpan Kaushik

E-mail: darpkaush@yahoo.com

Dhaka Univ. J. Pharm. Sci. 9(1): 61-64, 2010 (June)
Diabetes has recognized as a genetic disorder, where glucose metabolism is altered. The ability of insulin to bring about such a dramatic reversal in the symptoms of diabetes, with a return to a "near normal' life expectancy, led the medical community to conclude that the problems of etiology and treatment had been resolved, but these conclusions were premature, whereas insulin does return control of blood glucose level and does offset the development of ketoacidosis, it doesn't appear to rectify all of the metabolic defects identifiable in the diabetic. ${ }^{1}$

It is thus evident that insulin therapy, as currently is not a panacea for diabetes mellitus. This realization has promoted to a great deal of research toward the development of more effective way of treating the disease and has led to the discovery of various hypoglycemic agents e.g. sulphonylurea, biguanide, recently developed glitazones. Though recently developed glitazones are also monitored for the hepatotoxic effect. Thus there is a need for better and safer hypoglycemic.

It is now well established that insulin resistance can result from a defect in the insulin receptor signaling system at a site post binding of insulin to its receptor. ${ }^{2}$ Insulin resistance is associated with a defect in protein tyrosine phosphorylation in the insulin signal transduction cascade. PTPase enzyme dephosphorylates the active form of insulin receptor and thus attenuates its tyrosine kinase activity. ${ }^{3}$ 
Insulin resistance is thus one of the obstacles which we confront while undergoing therapy for diabetes mellitus. A number of PTPase inhibitors has been designed and studied to overcome this problem, to gain insight into the structural and molecular requirements influencing the PTPase-1B inhibition activity. Here we describe the QSAR analysis of a set of structurally different compounds of PTPase inhibitors, for which it is conceivable to make assumption that they interact with the enzyme.

Malamas $^{4}$ et al reported seven series of compounds based on benzofuran / benzothiophene biphenyl moiety. We had performed the QSAR analysis of 2-butyl benzofuran biphenyls (Table 1) \& 2-butyl benzofuran naphthalene (Table 2) having $7 \&$ 12 compounds [Structure $1 \& 2$ ] respectively. 2D QSAR study was carried out in the following steps:

Table 1. Chemical \& biological data of 2-Butyl Benzofuran Biphenyl Analogs [Structure 1]

\begin{tabular}{cccccc}
\hline Compd & $\mathrm{R}^{1}$ & $\mathrm{R}^{2}$ & $\mathrm{R}^{3}$ & $\mathrm{X}$ & $\mathrm{IC}_{50}$ \\
\hline 1 & $\mathrm{H}$ & $\mathrm{H}$ & $\mathrm{H}$ & $\mathrm{CH}_{2}$ & 1.19 \\
2 & $\mathrm{H}$ & $\mathrm{H}$ & $\mathrm{H}$ & $\mathrm{CH}(\mathrm{OH})$ & 0.23 \\
3 & $\mathrm{H}$ & $\mathrm{Br}$ & $\mathrm{Br}$ & $\mathrm{CH}(\mathrm{OH})$ & 1.4 \\
4 & $\mathrm{CH}_{2} \mathrm{COOH}$ & $\mathrm{H}$ & $\mathrm{H}$ & $\mathrm{CH}_{2}$ & 1.15 \\
5 & $\mathrm{CH}_{2} \mathrm{COOH}$ & $\mathrm{H}$ & $\mathrm{H}$ & $\mathrm{CH}(\mathrm{OH})$ & 0.54 \\
6 & $\mathrm{CH}_{2}$-tetrazole & $\mathrm{H}$ & $\mathrm{H}$ & $\mathrm{CH}_{2}$ & 0.51 \\
\hline
\end{tabular}

Table 2. Chemical and Biological Data of 2-Butyl Benzofuran Naphthalenes Analogs [Structure 2]

\begin{tabular}{ccccc}
\hline Comp & $\mathrm{R}^{1}$ & $\mathrm{R}^{2}$ & $\mathrm{X}$ & $\mathrm{IC}_{50}$ \\
\hline 1 & $\mathrm{H}$ & $\mathrm{H}$ & $\mathrm{CH}_{2}$ & 1.3 \\
2 & $\mathrm{H}$ & $\mathrm{H}$ & $\mathrm{CH}(\mathrm{OH})$ & 1.1 \\
3 & $\mathrm{H}$ & $\mathrm{Br}$ & $\mathrm{CH}(\mathrm{OH})$ & 0.48 \\
4 & $\mathrm{H}$ & $\mathrm{Br}$ & $\mathrm{CH}_{2}$ & 0.33 \\
5 & $\mathrm{H}$ & $\mathrm{I}$ & $\mathrm{CH}_{2}$ & 0.38 \\
6 & $\mathrm{CH}_{2} \mathrm{COOH}$ & $\mathrm{Br}$ & $\mathrm{CH}_{2}$ & 1.4 \\
7 & $\mathrm{CH}\left(\mathrm{CH}_{2} \mathrm{Ph}\right) \mathrm{COOH}$ & $\mathrm{Br}$ & $\mathrm{CH}_{2}$ & 0.37 \\
8 & $\mathrm{CH}\left(\mathrm{CH}_{2} \mathrm{Ph}\right) \mathrm{COOH}$ & $\mathrm{Br}$ & $\mathrm{CO}^{2}$ & 1.2 \\
9 & $\mathrm{CH}\left(\mathrm{CH}_{2} \mathrm{Ph}\right) \mathrm{COOH}$ & $\mathrm{I}$ & $\mathrm{CH}_{2}$ & 0.32 \\
10 & $\mathrm{CH}_{2}$-tetrazole & $\mathrm{Br}$ & $\mathrm{CH}_{2}$ & 0.7 \\
11 & $\mathrm{CH}_{2}$-tetrazole & $\mathrm{Br}$ & $\mathrm{CO}^{2}$ & 1.1 \\
\hline
\end{tabular}

Calculations of physico-chemical constants from literature ${ }^{5}$. The values for the physicochemical constants for various substituents were determined from the literature. The determined parameters for series VI included. Hansch constant $(\pi)$, Molar Refractivity $(\eta)$, Sigma/Hammet constant $(\sigma)$, Field effect (f) and Indicator value (I).
The substituents in the Structure 1:

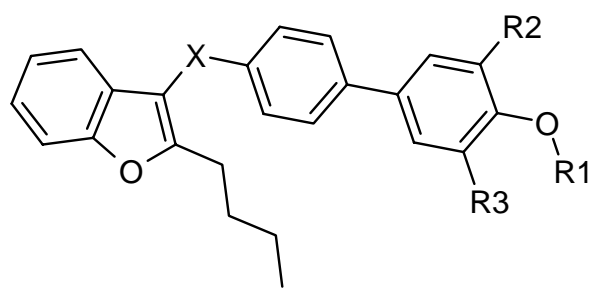

For Series III: $\mathrm{IR}^{1}, \mathrm{IR}^{2}, \mathrm{IR}^{3}, \pi \mathrm{X}, \sigma \mathrm{X}, \eta \mathrm{X}, \mathrm{fX}$

$\mathrm{IR}^{1}$ (Indicator parameter of $\mathrm{R}^{1}$ substituent)

$\mathrm{IR}^{1}=1$, where $-\mathrm{CH}_{2} \mathrm{COOH}$ present at $\mathrm{R}^{1}$ position, otherwise, considered as 0 .

$\mathrm{IR}^{2}$ (Indicator parameter for $\mathrm{R}^{2}$ substituent)

$\mathrm{IR}^{2}=1$, where $-\mathrm{H}$ is at $\mathrm{R}^{2}$ position, otherwise, rest other as 0 .

$\mathrm{IR}^{3}$ (Indicator parameter for $\mathrm{R}^{3}$ substituent)

$\mathrm{IR}^{3}=1$, where $\mathrm{H}$ is at $\mathrm{R}^{3}$ position, otherwise, other substituent considered as 0 .

$\pi \mathrm{X}, \sigma \mathrm{X}, \quad \eta \mathrm{X}, \mathrm{fX}$ are the physicochemical parameters for substitution $\mathrm{X}$.

The substituent in Structure II:

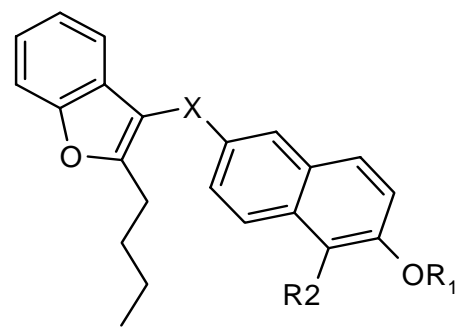

For Series $V$ : $I R^{1}, I R^{2}, \pi R^{1}, \sigma R^{1}, \eta R^{1}, f R^{1}, \pi X$, $\sigma \mathrm{X}, \eta \mathrm{X}, \mathrm{fX}$

$\mathrm{IR}^{1}$ (Indicator parameter for $\mathrm{R}^{1}$ substituent)

$\mathrm{IR}^{1}=1$, where $-\mathrm{CH}_{2} \mathrm{COOH}$ present at $\mathrm{R}^{1}$ position, otherwise 0 .

$\mathrm{IR}^{2}$ (Indicator parameter for $\mathrm{R}^{2}$ substituent)

$\mathrm{IR}^{2}=1$, where $-\mathrm{H}$ is at $\mathrm{R}^{2}$ position, other substituent considered as 0 .

$\pi \mathrm{R}^{1}, \quad \sigma \mathrm{R}^{1}, \quad \eta \mathrm{R}^{1}, \quad \mathrm{fR}^{1}$ are the physiochemical parameters of $\mathrm{R}^{1}$ substituent.

$\pi \mathrm{X}, \quad \sigma \mathrm{X}, \quad \eta \mathrm{X}, \quad \mathrm{XX}$ are the physiochemical parameters of $\mathrm{X}$ substituent. 
Determination of the correlation matrix. The correlation matrix for series III \& V was determined separately using the program 'SYSTAT' (version 7.0). The most significant parameters for PTPase inhibiting activity were chosen on the basis of their correlationship \& interco-relationship (Tables 3-4) respectively.
Multiple regression analysis. It was performed by using the program 'SYSTAT' (version 7.0) for PTPase inhibiting activity of benzofuran derivatives, i.e. $-\log \mathrm{IC}_{50}$ considered as dependent variable and the different descriptor considered were selected as the independent variables separately for series III \& $\mathrm{V}$.

Table 3. Correlation matrix [Structure 1]

\begin{tabular}{cccccccc}
\hline & $\operatorname{LogIC} 50$ & $\mathrm{IR}^{1}$ & $\mathrm{IR}^{2}$ & $\mathrm{IR}^{3}$ & $\pi \mathrm{X}$ & $\sigma \mathrm{X}$ & $\eta \mathrm{X}$ \\
\hline $\operatorname{LogIC}_{50}$ & 1.000 & & & & & & \\
$\mathrm{IR}^{1}$ & 0.126 & 1.000 & & & & & \\
$\mathrm{IR}^{2}$ & -0.485 & 0.316 & 1.000 & & & & \\
$\mathrm{IR}^{3}$ & -0.485 & 0.316 & 1.000 & 1.000 & & & \\
$\pi \mathrm{X}$ & 0.386 & 0.010 & 0.434 & 0.434 & 1.000 & & \\
$\sigma \mathrm{X}$ & 0.365 & 0.000 & 0.447 & 0.447 & 1.000 & 1.000 & \\
$\eta \mathrm{X}$ & -0.365 & 0.000 & -0.447 & -0.447 & -1.000 & -1.000 & 1.000 \\
$\mathrm{fX}$ & -0.365 & 0.000 & -0.447 & -0.447 & -1.000 & -1.000 & 1.000 \\
\hline
\end{tabular}

Table 4. Correlation matrix [Structure 2]

\begin{tabular}{|c|c|c|c|c|c|c|c|c|c|c|c|}
\hline & $\log \mathrm{IC}_{50}$ & $\mathrm{IR}^{1}$ & $\mathrm{IR}^{2}$ & $\pi \mathrm{X}$ & $\eta X$ & fX & $\sigma \mathrm{X}$ & $\pi \mathrm{R}^{1}$ & $\eta R^{1}$ & $\sigma \mathrm{R}^{1}$ & $\mathrm{fR}^{1}$ \\
\hline $\begin{array}{l}\mathrm{Log} \\
\mathrm{IC}_{50}\end{array}$ & 1.000 & & & & & & & & & & \\
\hline $\mathrm{IR}^{1}$ & -0.013 & 1.000 & & & & & & & & & \\
\hline $\mathrm{IR}^{2}$ & 0.469 & -0.356 & 1.000 & & & & & & & & \\
\hline$\pi \mathrm{X}$ & -0.201 & 0.321 & -0.326 & 1.000 & & & & & & & \\
\hline$\eta X$ & -0.068 & -0.358 & 0.412 & -0.826 & 1.000 & & & & & & \\
\hline fX & 0.139 & -0.341 & 0.359 & -0.990 & 0.900 & 1.000 & & & & & \\
\hline$\sigma \mathrm{X}$ & 0.296 & 0.411 & -0.343 & 0.381 & -0.799 & -0.501 & 1.000 & & & & \\
\hline$\pi \mathrm{R}^{1}$ & -0.273 & 0.810 & -0.289 & 0.218 & -0.327 & -0.253 & 0.468 & 1.000 & & & \\
\hline$\eta \mathrm{R}^{1}$ & -0.265 & 0.823 & -0.243 & 0.223 & -0.331 & -0.258 & 0.469 & 1.000 & 1.000 & & \\
\hline$\sigma \mathrm{R}^{1}$ & 0.273 & 0.810 & 0.289 & -0.218 & 0.327 & 0.253 & -0.468 & 1.000 & 1.000 & 1.000 & \\
\hline $\mathrm{fR}^{1}$ & 0.273 & -0.810 & 0.289 & -0.218 & 0.327 & 0.253 & -0.468 & 1.000 & 1.000 & 1.000 & 1.000 \\
\hline
\end{tabular}

The significant equation obtained for series III \& $\mathrm{V}$ are equation $1,2 \& 3$ respectively:

$$
\begin{aligned}
& -\log \mathrm{IC}_{50}=0.595( \pm 0.297) \pi \mathrm{X}-0.594( \pm 0.271) \mathrm{IR}^{2}+ \\
& 0.212( \pm 0.225) \\
& \mathrm{n}=6, \mathrm{r}=0.82, \mathrm{~s}=0.223, \mathrm{~F}=3.088 \ldots \ldots \ldots \ldots \ldots(1) \\
& -\log \mathrm{C}_{50}=0.772( \pm 0.254) \pi \mathrm{X}-0.591( \pm 0.212) \mathrm{IR}^{2}+ \\
& 0.231( \pm 0.176) \\
& \mathrm{n}=5, \mathrm{r}=0.927, \mathrm{~s}=0.174, \mathrm{~F}=6.134 \quad \ldots \ldots \ldots(2) \\
& -\log \mathrm{C}_{50}=0.471( \pm 0.173) \pi \mathrm{X}+0.482( \pm 0.137) \mathrm{IR}^{2}- \\
& 0.329( \pm 0.061) \\
& \mathrm{n}=10, \mathrm{r}=0.824, \mathrm{~s}=0.163, \mathrm{~F}=7.408 \ldots \ldots . .(3)
\end{aligned}
$$

In eq. (1) of series III only 6 subjects were considered because of the non availability of exact $\mathrm{IC}_{50}$ of one of the compounds but for the same series in eq. (2) only 5 subjects were considered, as compound 6 was considered as an outlier as its residual value exceeds the average value, whereas in series $\mathrm{V}$ also, only 11 subjects were considered because of the absence of same exact $\mathrm{IC}_{50}$ problem but eq. (3) which was generated for this series had only 10 subjects because subject 6 here too considered as an outlier.

From this data analysis, we can conclude that for series III \& V for all the eq. any substituent which is going to increase the hydrophobic character at $\mathrm{X}$ 
position is going to increase the activity of compound but for series III, the result are not significant in term, as number of variable for the number of subject considered is more than the specified limit of 1: 5 , moreover when critical values of the Pearson product-moment correlation coefficient is checked at $\mathrm{P}>.05$, then for eq.(1) \& (2) both found to be non significant as the observed $\mathrm{r}$ value is found to be less than theoretical value but for eq. (3) the result shows the $99 \%$ significance as $\mathrm{P}<0.01$ as the observed value is much more than theoretical value $r=0.798$. This gives us an inference that the hydrophobic character at $\mathrm{X}$ is essential for the designing of the new PTPase1B inhibitors of naphthalene analogs but not for the biphenyl derivatives as also observed in previous QSAR studies on biphenyl derivatives.

Finally, it can be concluded that the work presented here will play an important role in understanding the relationship of physicochemical parameters with structure and biological activity of the PTPase 1B inhibitor and will help in choosing the suitable substituent for getting the active compound with maximum potency.
The authors are grateful to the Director, CDRI, Lucknow \& Dr. A.K Saxena for providing necessary facilities. Darpan Kaushik is grateful to UGC for providing financial assistantship during this project.

\section{REFERENCES}

1. Foye, W.O. 1989. Principles of Medicinal Chemistry, Varghese Publishing House, Bombay, $3^{\text {rd }}$ edition, pp 531.

2. Haring, HU. 1991. The Insulin receptor: Signaling mechanism and contribution to the pathogenesis of insulin resistance. Diabetologia 34, 848-861.

3. Goldstein, B.J. 1992. Protein- Tyrosine Phosphatases and the regulation of insulin action. J. Cell. Biochem. 31, 33-42.

4. Malamas, M.S., Sredy, J., Moxham, C., Katz, A., W.Xu, McDevitt, R., Adebayo, F.O., Sawicki, D.R., Seestaller, L., Sullivan, D. and Taylor; J.R.2000. Novel benzofuran and benzothiophene biphenyls as inhibitors of protein tyrosine phosphatase 1B with Antihyperglycemics properties. J. Med. Chem. 43, 1293-1310.

5. Hansch, C and Leo, A.1979. Substituent constants for correlation analysis in chemistry and biology, John Wiley and Sons, New York, p. 48.

6. Systat, (version 7.0). S.P.S.S., Inc., 944, North Michigan Avenue, Chicago, IL 60611.U.S. 